\title{
VIRTUAL REALITY PENGENALAN KAMPUNG TRADISIONAL MINANG KABAU BERBASIS ANDROID
}

\author{
Rini Sovia ${ }^{1)}$, Muhammad Reza Putra ${ }^{2)}$, Randy Permana $^{3)}$, dan Adiddo Restiady ${ }^{4)}$ \\ 1,2,3,4 Teknik Informatika, Fakultas Ilmu Komputer \\ 1,2,3,4 jln. Raya Lubuk Begalung, Padang, 25221 \\ E-mail : rini_sovia@upiyptk.ac.id ${ }^{1)}$, muhammad_reza@upiyptk.ac.id ${ }^{2)}$,randy_permana@upiyptk.ac.id ${ }^{3)}$, \\ adiddorestiady@gmail.com ${ }^{4}$
}

\begin{abstract}
ABSTRAK
Teknologi Virtual Reality merupakan salah satu teknologi yang memungkinkan komputer untuk menyimulasikan suatu lingkungan virtual yang dapat berinteraksi dengan pengguna secara realtime dan berkelanjutan. Tidak sama seperti teknologi simulasi lainnya yang hanya mengandalkan interaksi melalui monitor dan input device seperti mouse dan keyboard, Virtual Reality lebih membawa pengalaman yang lebih baik kepada pengguna seolah - olah pengguna benar benar berada dilingkungan Virtual tersebut. Virtual Reality menggabungkan pengindraan manusia seperti vision ( penglihatan ), Pendengaran, Sentuhan dan juga penciuman yang tergabung didalam suatu dunia virtual berbentuk 3D. Penerapan teknologi Virtual Reality saat ini telah merambah berbagai displin ilmu dan bidang seperti edukasi atau pendidikan, kesehatan, Militer, Psikologi, dan juga Hiburan. Pada penelitian ini, Virtual Reality dimanfaatkan sebagai media untuk mengedukasi masyarakat umum dan khususnya generasi muda suku Minangkabau untuk lebih mengenal kebudayaan yang telah mereka terima secara turun temurun. Melalui teknologi ini, lingkungan virtual 3D akan menyimulasikan keadaan kampung tradisional minangkabau dan mengajak pengguna untuk berinteraksi secara langsung dengan lingkungan virtual tersebut. Sistem Virtual Reality akan menampilkan dan memperkenalkan kembali bentuk struktur bangunan tradisional Minangkabau yang mulai saat ini sudah mulai jarang ditemui dalam kehidupan nyata.
\end{abstract}

Kata Kunci: 3D, Lingkungan Virtual, Menyimulasikan, Minangkabau, Virtual Reality

\section{PENDAHULUAN}

Masyarakat Minang kalau dilihat dari luar merupakan suatu kelompok masyarakat tunggal, sebagai salah satu Suku bangsa tau etnis yang dikenal dengan sebutan etnis Minangkabau ( Amir, 2013 ).

Namun jika dilihat kedalam, masyarakat Miangkabau tersusun dari berbagai kelompok kecil yang bermula dari kelompok Rumah Tanggo, kemudian membesar menjadi kelompok Samande, Sajurai, Saparuik, Sasuku, Sakampuang (Ba Kaampek Suku), Sasudut dan akhirnya sebagai kelompok terbesar Sanagari ( Amir, 2013 ).

Pada era globalisasi ini semakin berkembangnya zaman, berbagai macam pengaruh budaya asing ke dalam masyarakat telah menyebabkan perubahan yang sangat drastis pada kehidupan sehari-hari terutama bagi masyarakat minang, khususnya generasi muda pada saat sekarang ini.

Sehingga budaya minang pada saat ini mulai terlupakan, seiring dengan perkembangan zaman, bentuk bangunan dari ciri khas minang (rumah adat) yang telah mulai berkurang menyebabkan generasi muda kurang mengetahui bentuk dan suasana kehidupan Minang pada zaman dahulu.

Untuk menjaga dan melestarikan nilai kebudayaan yang mulai terlupakan itu maka diperlukan sebuah media pembelajaran tentang kampung tradisional Minangkabau pada zaman dahulu dengan menggunakan teknologi Virtual Reality. Teknologi ini akan mengajak pengguna untuk melakukan eksplorasi atau penjelajahan terhadap dunia virtual yang diciptakan menyerupai keadaan kampung Minangkabau dan menampilkan berbagai struktur tradisional virtual yang terdapat didalam sistem virtual.

Virtual reality memiliki potensial yang sangat baik untuk dikembangkan mengingat pengalaman yang diberikan oleh Virtual Reality baik dari segi pengalaman bekerja, pengalaman dalam hiburan maupun pengalaman didalam bersosial.

Penelitian yang sebelumnya Sihite (2013), menerapkan teknologi Virtual Reality sebagai media pembelajaran sejarah kemerdakaan indonesia dengan menggunakan setting sejarah perobekan bendera Belanda di hotel Majapahit. Konsep yang ditekankan pada penelitian tersebut adalah dengan membuat pengguna seolah - olah melihat langsung bangunan hotel dan setting tempat terjadinya peristiwa bersejarah tersebut. Selain itu Wardijono (2015) menerapkan Virtual Reality sebagai media pembelajaran monumen - monumen nasional yang terdapat di daerah Indonesia. Kelebihan yang dimiliki oleh penelitian ini adalah kemampuan sistem untuk mengajak user menjelajahi lingkungan virtual dengan banyak monumen - monumen bersejarah yang telah diduplikasi menjadi objek 3D. Minocha (2015 ) menyatakan bahwa virtual reality memiliki potensi yang sangat baik didalam dunia pendidikan. Berdasarkan hasil penelitian yang dilakukan oleh Minocha, dengan menggunakan headset Virtual reality membantu memberikan pemahaman dan pengalaman yang lebih 
baik lagi didalam melakukan pembelajaran, namun tentunya penggunaan teknologi ini tetap harus dibatasi agar tetap menjaga komunikasi dan tatap muka antara peserta didik dan tenaga pendidik.

Joshi ( 2015 ) melakukan penelitian Virtual reality dalam bentuk sebuah permainan berbasis mobile dengan sistem operasi android. Game Virtual menggunakan sebuah perangkat google Cardboard atau sejenis alat yang digunakan untuk menjadikan Smartphone yang dimiliki menjadi perangkat Virtual Reality. Game bekerja dengan menerapkan sedikit konsep dari Augmented Reality dimana sejumlah marker atau pola yang telah disimpan didalam Database program akan dirender oleh mobile device begitu user mengarahkan kamera kearah marker tersebut. Hasil dari penelitian tersebut menyatakan bahwa teknologi Virtual menyajikan pengalaman baru didalam permainan berbasis mobile Android.

Penelitian Ryadi (2017) memanfaatkan teknologi Virtual Reality sebagai media untuk melakukan pengenalan terhadap kampus politeknik Indramayu. Konsep yang digunakan hampir sama dengan yang dilakukan oleh Joshi, namum penelitian Ryadi tidak memerlukan marker sebagai media interaksi terhadap sistem. Sistem Virtual Reality yang dikembangkan memanfaatkan sensor Accelerometer dan sensor Gyroscope sebagai media input untuk berinteraksi dengan dunia virtual.

\section{RUANG LINGKUP}

Dalam penelitian ini permasalahan mencakup:

\subsection{Cakupan Permasalahan}

Berdasarkan pendahuluan yang telah diuraikan di atas, maka dapat dirumuskan beberapa rumusan masalah yaitu sebagai berikut:

1. Bagaimana masyarakat Minangkabau dapat mengenal kampung zaman dahulu?

2. Bagaimana memperkenalkan suasana kehidupan Minangkabau pada zaman dahulu terhadap generasi muda?

3. Bagaimana cara memanfaatkan sarana teknologi informasi dalam pelestarian gambaran budaya alam Minangkabau?

\subsection{Batasan Permasalahan}

Berikut merupakan batasan terhadap permasalahan yang akan dibahas pada penelitian ini:

1. Target dari pengguna Virtual Reality merupakan anak sekolah dasar hingga anak tingkat SLTA.

2. Virtualisasi hanya mencakup beberapa rumah gadang, area persawahan, dan sungai seperti layaknya perkampungan pada zaman dahulu.

3. Didalam Virtual Reality ini hanya menampilkan beberapa ruangan dalam rumah gadang Minangkabau.

\subsection{Rencana Hasil Penelitian}

Berikut merupakan rencana hasil penelitian yang akan dihasilkan :

1. Dengan adanya Virtual Reality berupa 3D diharapkan nantinya dapat mengenalkan kampung zaman dahulu kepada masyarakat Minangkabau saat ini.

2. Diharapkan nantinya dengan adanya Virtual Reality dapat memperkenalkan suasana kehidupan Miangkabau pada zaman dahulu terdap generasi muda.

3. Dengan adanya teknologi Virtual Reality dapat membantu melestarikan gambaran budaya alam Minagkabau berupa visual animasi 3D.

\section{BAHAN DAN METODE}

Berikut merupakan bahan dan metode yang diperlukan didalam melakukan pembangunan sistem Virtual Reality kampung tradisional minangkabau, antara lain :

\subsection{Virtual Reality}

Menurut Bamodu ( Suryani, 2016 ) Virtual Reality (VR) merupakan sebuah media interaksi antara manusia dan komputer dalam bentuk interaksi secara virtual yang dapat menghadirkan efek perasaan nyata dalam lingkungan virtual melalui berbagai feedback seperti sensor kanal virtual, aura, sentuhan, bau-bauan, dan sebagainya. Selian itu, didalam pengembangan Virtual Reality ini melibatkan multidisiplin ilmu dalam ilmu komputer seperti komputer grafis, pengolahan citra, pengenalan pola dan kecerdasan buatan, jaringan, dan multimedia.

Masih menurut Bamodu ( Suryani, 2016 ), Virtual Reality mengedepankan konsep 3I, yaitu: Immersion, Interaction, dan Imagination. Immersion merupakan aspek perasaan kehadiran diri sendiri di dalam lingkungan digital yang dibangun. Interaction merupakan cara pengguna melakukan komunikasi terhadap sistem Virtual Reality dalam lingkungan 3D. Imagination merupakan kemampuan dari para pengembang sistem virtual dialam menyampaikan konsep pemikiran kedalam produk Virtual Reality.

Menurut Suyanto ( dalam Fahrudin 2015), Virtual Reality merupakan sebuah realitas gabungan atau disebut dengan mixed reality.

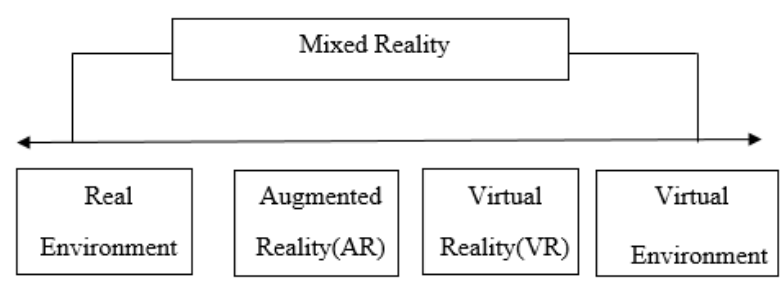

Gambar 1. Mixed Reality 
Gambar tersebut menjelaskan dua jenis Mixed Reality yaitu Augmented Reality dan Virtual Reality. Perbedaan yang mendasar dari kedua jenis ini terletak pada penggunaan environment ( lingkungan ), dimana Augmented reality mengandalkan lingkungan asli sebagai media untuk menyampaikan informasi, sementara Virtual reality menggunakan lingkungan virtual seutuhnya sebagai media penyampaian informasi.

Virtual Reality memudahkan pengguna didalam melakukan proses pembelajaran dikarenakan teknologi ini memanfaatkan visualisasi sebagai media untuk pengantar materi pembelajaran ( Wardijono). Teknologi Virtual Reality dikenalkan pada tahun 1960-an dalam penggambaran sebuah ruang lingkup yang disajikan dalam dengan menggunakan bantuan pengolahan dari sistem komputer ( Wardijono ).

\subsection{Unity}

Sudyatmika ( Muthia, 2015 ), menjelaskan unity adalah sebuah tools pengolahan objek 3D yang dikhususkan untuk membuat videogame maupun animasi 3D virtual . Lingkungan dari pengembangan Unity 3D berjalan pada Microsoft Windows dan Mac Os X, serta aplikasi yang dibuat oleh Unity 3D dapat berjalan pada Windows, Mac, Xbox 360, Playstation 3, Wii, iPad, iPhone dan tidak ketinggalan pada platform Android selain itu unity juga mensupport game berbasis browser dengan tools unity webplayer yang dapat berjalan disistem operasi Mac dan Windows.

\subsection{Vuvoria Engine}

Vuvoria merupakan sebuah SDK ( software development Kit ) untuk mobile device yang memungkinkan pembuatan sistem mixed reality ( augmented reality dan virtual reality). Software ini menyediakan API ( application Programming Interface ) dalam bentuk bahasa pemrograman $\mathrm{C}++$, Java, dan $\mathrm{C}++$ berorientasi objek. Vuvoria sangat kompatibel dengan unity engine ( software utama pengolah mixed reality) dan menghasilkan sistem tidak hanya berbasis android namun juga berbasis IOS.

\subsection{Blender 3D}

Blender merupakan software pengolahan multimedia 3D dengan lisensi bebas atau bersifat open source, sehingga user padat menggunakannya secara gratis dan berkontribusi dalam pengembangan software tersebut ( Yulsilviana, 2017 ).

Berikut merupakan kelebihan Software Blender ( Yulsilviana, 2017) :

1. Software Blender banyak diguanakan sebagai media pemodelan $3 \mathrm{~d}$ untuk pembuatan karakter 3D.

2. Memiliki tools pewarnaan yang sangat baik.

3. Memiliki fasilitas rigging untuk membentuk pergerakan animasi.

4. Memiliki mesin rendering animasi.
5. Memiliki modul untuk melakukan compositing secara realtime sehingga setiap perubahan yang terjadi diobject dapat dilihat secara langsung.

6. Memiliki fasilitas game enggine untuk melakukan perancangan sebuah game.

\subsection{Android}

Sulihati (2016) menjelaskan bahwa Android merupakan sistem operasi dengan basis Linux yang dikembangkan untuk perangkat mobile seluler. Selain itu Android menyediakan platform terbuka bagi para pengembang untuk menciptakan aplikasi mereka sendiri untuk digunakan oleh bermacam Mobile Device.

Android mulai dikembangkan semenjak tahun 2003 dengan beranggotakan empat orang tim pakar IT ( Information Technology ). Pengembangan sistem operasi tersebut menarik minat perusahaan raksasa Google untuk mengakusisi android pada tahun 2005. Sampai saat ini android menjadi salah satu sistem operasi standar bagi sebuah smartphone dan google terus melakukan pengembangan terhadap sistem operasi tersebut.

\section{PEMBAHASAN}

Bagian ini akan menjelaskan perancangan sistem Virtual Reality pembelajaran kampung tradisional Minangkabau.

\subsection{Perancangan Konseptual}

Perancangan konseptual merupakan bagian yang menjelaskan bagaimana sistem Virtual Reality dirancang dengan menggunakan tools pemodelan yang disebut dengan UML ( Unified Modelling Languange) berikut merupakan pemodelan sistem.

1. Use case Diagram

Use Case diagram menggambarkan interaksi pengguna terhadap sistem.

Pada perancangan Virtual Reality terdapat beberapa interaksi yang bisa dilakukan pengguna terhadap sistem seperti tergambar pada gambar 2 .

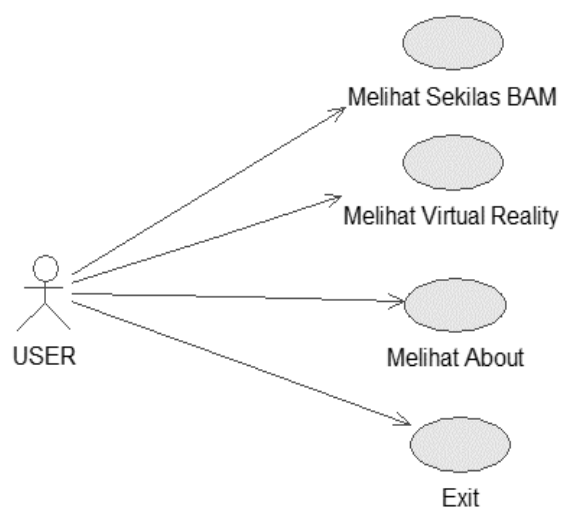

Gambar 2. Use Case Diagram 
Interaksi yang dilakukan oleh user terhadap sistem Virtual Reality yaitu sebagai berikut :

1) Melihat Sekilas Bam, hasil interaksi akan memungkinkan pengguna untuk dapat membuka informasi - informasi yang bekaitan dengan alam Minangkabau, salah satu informasi yang ditampilkan adalah mengenai rumah adat minangkabau meliputi tujuan, model dan apa kegunaan dari rumah gadang tersebut.

2)Melihat Virtual Reality, hasil interaksi pengguna terhadap use case ini adalah memungkinkan pengguna untuk mengakses langsung dunia virtual perkampungan Minangkabau.

3)Melihat About, interaksi ini menyediakan informasi tentang pengoperasian sistem ini.

4)Exit, interaksi ini memungkinkan pengguna untuk keluar dari sistem.

2. Class Diagram

Class Diagram menitik beratkan untuk menjelaskan komponen - komponen objek yang terdapat didalam pembangun sistem Virtual Reality.

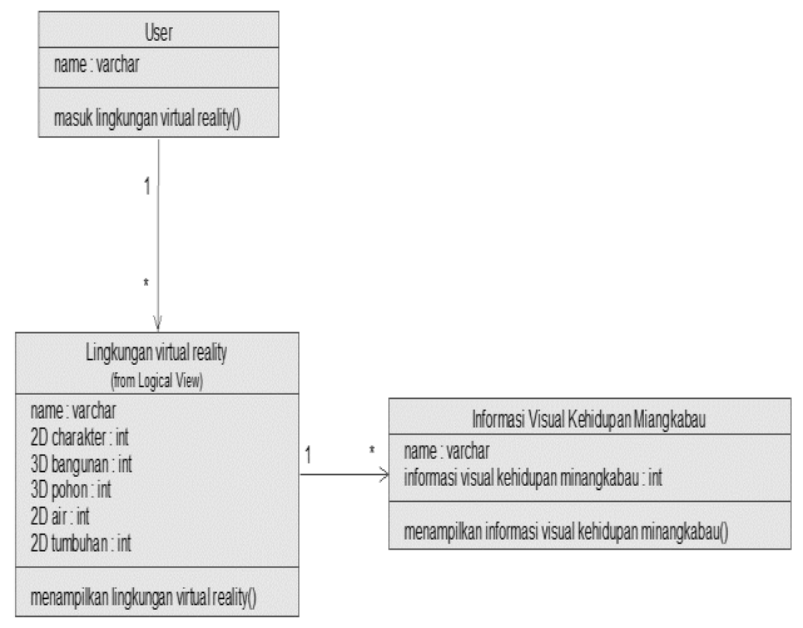

Gambar 3. Class Diagram

Seperti yang dipaparkan pada gambar terdapat tiga objek utama dari penyusun Virtual Reality ini. Objek user mewakili pengguna dari sistem, objek lingkungan atau environment dan objek informasi mewakili komponen informasi - informasi yang ditampilkan kepada pengguna didalam sistem.

\section{Activity Diagram}

Mengambarkan aliran aktifitas dam sistem yang akan dirancang, mulai dari awal sistem sampai akhir sistem. Activity Diagram dimulai dengan simbol start dan berakhir dengan simbol stop.

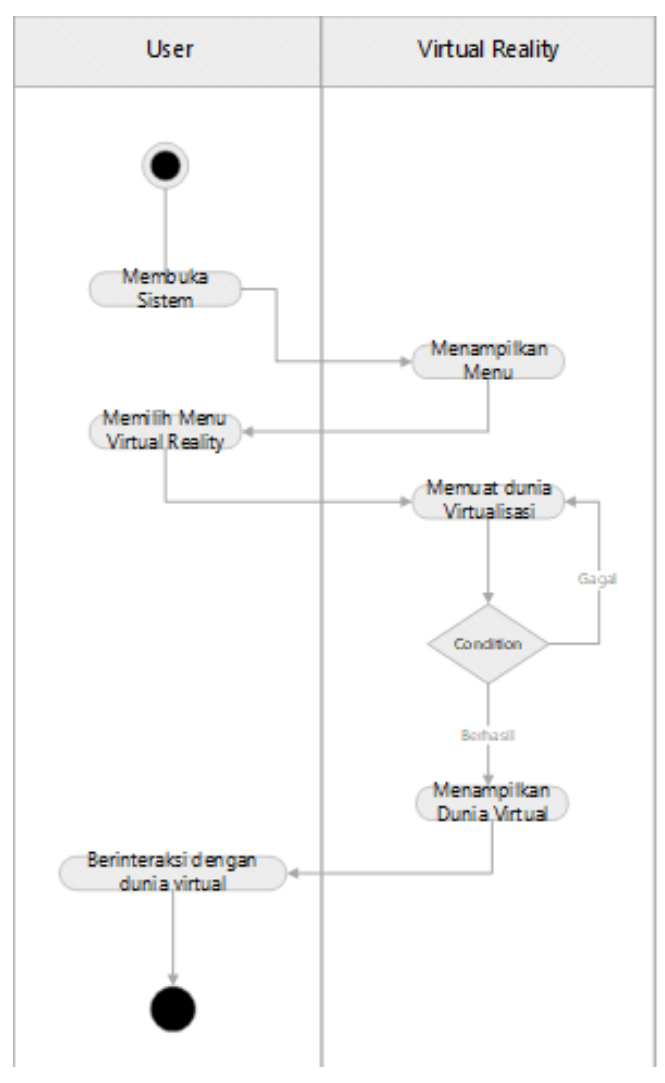

\section{Gambar 4 . Activity Diagram}

Aktivitas yang paling dominan dari sistem Virtual Reality adalah ketika pengguna melakukan aktivitas didalam dunia virtual yang telah dibentuk sebelumnya. User mengaktifkan sistem dan sistem merespon dengan menampilkan antar muka utama yang dapat dipilih oleh seorang user. Kegiatan berlanjut setelah user memilih menu virtual reality, dimana terdapat dua kondisi antara sistem sukses memuat dunia virtual reality atau sistem gagal didalam memuat dunia virtual. Setelah dunia virtual dimuat maka user dapat berinteraksi dan melakukan penjelajahan terhadap dunia virtual.

\subsection{Perancangan Antar Muka Virtual Reality}

Desain interface adalah bentuk rancangan tampilan sistem Virtual Reality yang dibangun. Perancangan ini dibuat untuk memberikan gambaran dari tampilan yang akan dilihat user pada saat mengunakan sistem, sehingga dapat mempermudah user dalam mengimplementasikan dan membangun sistem yang dapat memenuhi prinsip perancangan antarmuka yang baik.

Pada tampilan di dalam smartphone sangat berbeda dari sistem biasanya, kita bisa menggunakan alat tambahan yaitunya headset $V R$ atau sering disebut google cardboard, kita akan masuk kedalam suasana kehidupan Minangkabau pada zaman daluhu dalam bentuk animasi visual yang dikenal sebagai Virtual Reality. Awal program atau tampilan interface akan lansung menampilkan menu dari sistem. 
1. Tampilan Home Sistem

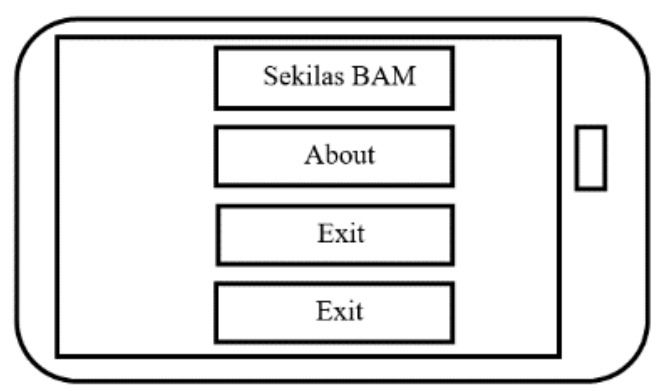

Gambar 5. Home Sistem Virtual Reality

Berdasarkan draft diatas pada bagian sekilas bam, merupakan bagian utama untuk mengakses Virtual Reality pada sistem ini, sementara bagian about berisi penjelasan dasar pengoperasian dari sistem ini.

2. Tampilan Virtual Reality

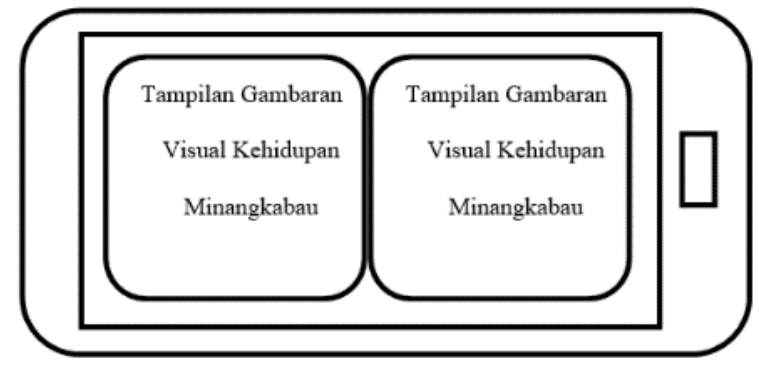

Gambar 6 . Tampilan Virtual Reality diaktifkan

Display dari aplikasi akan membagi yampilan menjadi dua, dimana tampilan yang digunakan untuk dilihat menggunakan mata kiri dan sebaliknya terdapat juga display untuk mata kanan.

\subsection{Implementasi Sistem Virtual Reality}

Berikut adalah antarmuka dari sistem/aplikasi yang dibangun:

\section{Interface Virtual Reality}

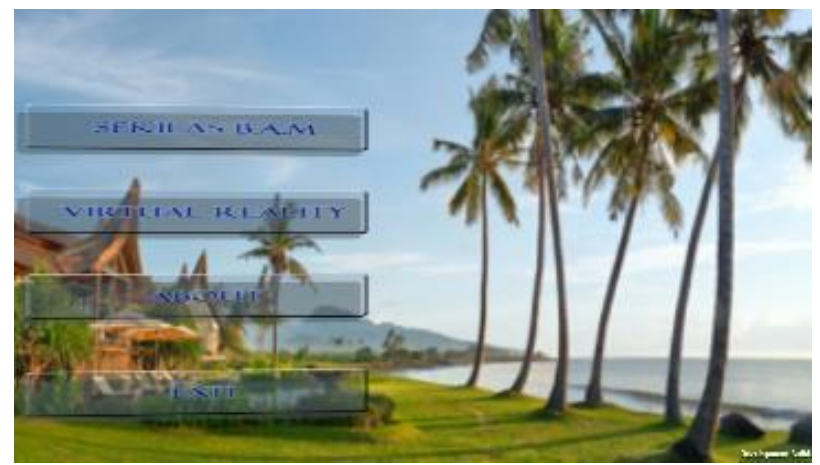

Gambar 7 Antar Muka Sistem
Gambar 7 memperlihatkan tampilan awal dari sistem Virtual Reality yang terdiri dari sekilas BAM, Virtual Reality dan About yang menjelaskan cara penggunaan sistem.

\section{Media view Virtual Reality}

Untuk bisa berinteraksi dengan Virtual Reality pengguna diharuskan menggunakan sebuah alat yang disebut dengan Vrbox. Vrbox adalah merupakan alat yang memungkinkan sebuah smartphone berubah menjadi VrHeadset.

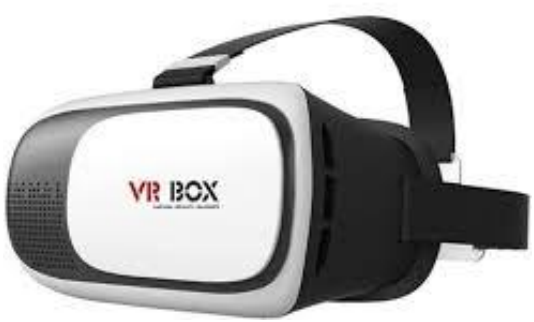

Gambar 8. VrBox

$V r$ Box sangat compatible dengan semua jenis smartphone dengan ukuran layar maksimal 6 inchi.

\section{Implementasi Virtual Reality}

Ketika program dijalankan, maka user akan disajikan dengan bentuk tampilan layar yang terbagi dua, dimana layar yang terbagi tersebut sama - sama menghasilkan gambar yang sama. Tujuan dari pembagian layar ini adalah untuk membuat efek penglihatan yang nyata kepada pengguna ketika menggunakan $\operatorname{VrBox}$.

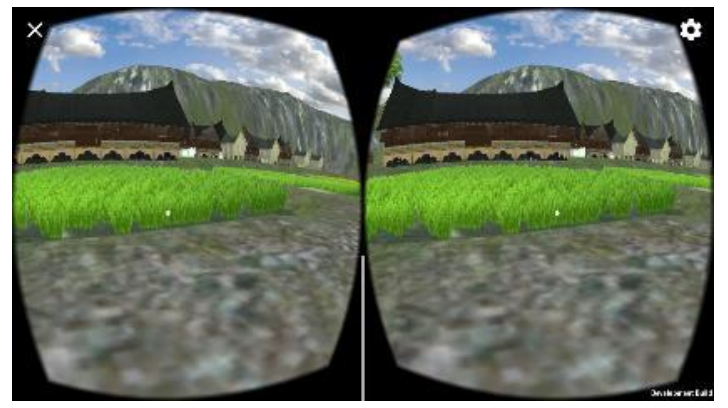

Gambar 9. View Virtual Reality

Dengan menggunakan VrBox, maka user akan mendapatkan satu pemandangan penuh dari lingkungan Virtual Reality. 


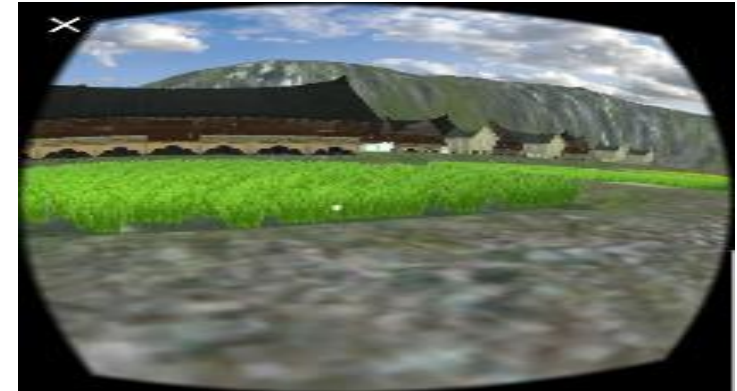

Gambar 10. View User Menggunakan VR Box

User dapat melakukan perjalanan virtual menyusuri kampung untuk menemukan bebrapa arsitektur tradisional masyarakat Minagkabau.

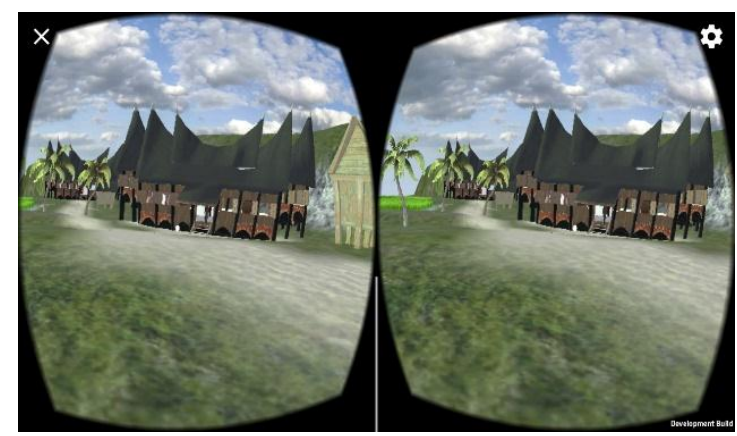

Gambar 11 . Bentuk bangunan Tradisional Minangkabau

Selain disuguhkan dengan arsitektur bangunan, user juga akan dberikan penjelasan mengenai bangunan yang sedang dijelajahi melalui objek informasi yang berada disekitar bangunan.

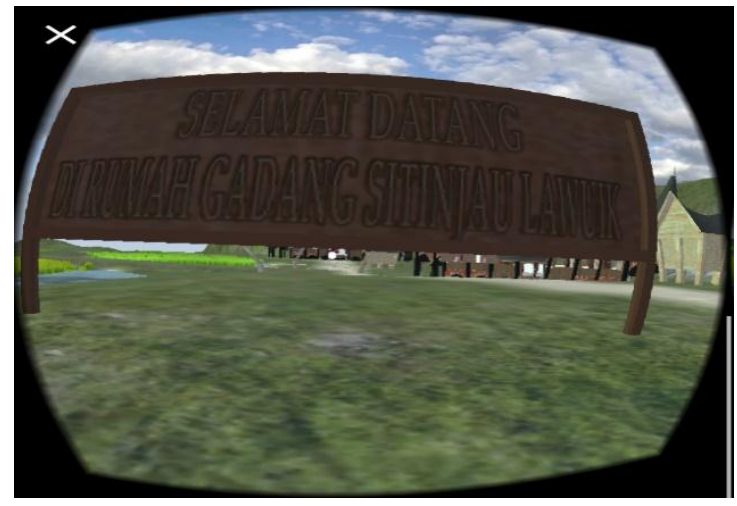

Gambar 12. Informasi Objek Arsitektur Virtual

Untuk menambah informasi kepada pengguna, maka objek virtual juga bisa dimasuki dan dijelajahi dari dalam ruangan untuk memperlihatkan layout arsitektur tradisional Minangkabau.

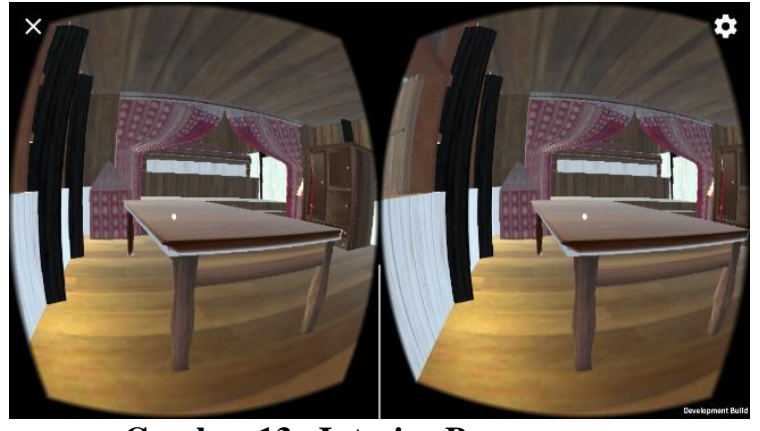

Gambar 13 . Interior Bangunan

\section{KESIMPULAN}

Virtual Reality merupakan teknologi yang akan terus mengalami kemajuan seiring dengan berkembangnya kemampuan dari teknologi mobile yang diciptakan oleh manusia. Virtual Reality memperluas sudut pandang kita didalam menerima dan mengolah informasi melalui pemanfaatan visualisasi 3D. Virtual Reality Kampung Tradisional Minangkabau memberikan kontribusi yang baik kepada generasi Minangkabau didalam mengenal kembali kebudayaan yang telah mereka terima secara turun termurun. Sehingga meskipun zaman telah berubah dan unsur - unsur kebudayaan secara fisik mulai berkurang, generasi muda Minangkabau masih dapat mengenal dengan baik kebudayaan mereka melalui lingkungan virtual yang disediakan oleh Virtual Reality.

\section{SARAN}

Virtual Reality Kampung tradisional Minangkabau baru menyajikan pengalaman visualisasi yang lebih baik kepada pengguna. Pengembangan lebih lanjut sangat dibutuhkan untuk membuat pengalaman menggunakan Virtual Reality menjadi lebih baik lagi seperti pengalaman sentuhan, pendengaran bahkan untuk membuat suasana menjadi lebih realistis diperlukan pengalaman aroma yang berkaitan dengan suasana perkampungan tradisional.

\section{DAFTAR PUSTAKA}

Amir, MS., 2013. Masyarakat Adat Minangkabau Terancam Punah Bagai Bajak Ndak Basingka., Jakarta: Citra Harta Prima.

Fahruddin, A. and Fitrianto, Y., 2015. Virtual Reality Photography untuk Media Promosi OnLine Objek Wisata Curug Tujuh Bidadari. Jurnal ilmiah komputer grafis, $8(1)$

Joshi, A.G., Dabhade, A.S. and Borse, A.S., 2015. VIRTUAL REALITY IN ANDROID GAMING.

Muthia and Djuniadi, 2015. Pengembangan Aplikasi Pengenalan Lingkungan Sekitar Dengan Menggunakan Engine Unity 3D. Universitas Negeri Semarang. Vol.22,No.3.

Minocha, S., 2015. The state of virtual reality in education-Shape of things to 
come. International Journal of Engineering Research, 4(11), pp.596-598.

Riyadi, F.S., Sumarudin, A. and Bunga, M.S., 2017. Sistem 3d virtual reality sebagai media pengenalan kampus politeknik negeri indramayu berbasis mobile. JIKO (Jurnal Informatika dan Komputer), 2(2), pp.75-82.

Sihite, B., Samopa, F. and Sani, N.A., 2013. Pembuatan Aplikasi 3D Viewer Mobile dengan Menggunakan Teknologi Virtual Reality (Studi Kasus: Perobekan Bendera Belanda di Hotel Majapahit). Jurnal Teknik ITS,2(2), pp.A397A400.

Sulihati and Andriyani. 2016. Aplikasi Akademik Online Berbasis Mobile Android Pada Universitas Tama Jagakarsa. Jurnal Sains dan Teknologi Utama. Vol.11,No.1. ISSN : 1978-001X

Suryani, M., Paulus, E. and Farabi, R., Semi-Immersive Virtual Reality untuk Meningkatkan Motivasi dan Kemampuan Kognitif Siswa dalam Pembelajaran
Wardijono, B.A., Hendajani, F., Sudiro, S.A. and Ramadhani, A.I., 2015. Pengembangan Model Grafik 3 Dimensi Monumen Nasional Dan Lingkungan Sekitarnya Dengan Teknologi Virtual Reality Berbasis Web. Prosiding Semnastek

Yulsilviana, E., Basrie, B. and Saputra, A.W., 2017. Implementasi Augmented Reality Pemasaran Rumah PT. Rika Bersaudara Sakti Menggunakan Metode Marker Based Tracking Pada Brosur Perumahan. Sebatik, 17(1), pp.11-15. 